\title{
COPPERAND ZINC QUANTIFICATION IN CONTAMINATED SOIL AS EVALUATED BY CHEMICAL EXTRACTANTS
}

\author{
Maria Ligia de Souza Silva'; Anderson Ricardo Trevizam²; Godofredo César Vitti* \\ ${ }^{1}$ USP/ESALQ - Programa de Pós-Graduação em Solos e Nutrição de Plantas. \\ ${ }^{2}$ USP/CENA - Programa de Pós-Graduação em Ciências, C.P. 96 - 13400-970 Piracicaba, SP - Brasil. \\ ${ }^{3}$ USP/ESALQ - Depto. Ciência do Solo, C.P. 09 - 13418-900 - Piracicaba, SP - Brasil. \\ *Corresponding author <gcvitti@esalq.usp.br>
}

\begin{abstract}
Trace elements are potentially toxic to the environment. Their toxicity in soils relies on their type of chemical associations. Hence it is important to determine the chemical form they occur in the soils in order to assess their quantities. The objective the present work was to evaluate the possibility of using the concentrations of $\mathrm{Cu}$ and $\mathrm{Zn}$ in different soil fractions and the total concentration as predictors of their quantification by comparing the classical extractants DTPA, Mehlich-1 and HCl. Comparisons were made also with the concentrations of absorbed by rice and soybean in contaminated soil. Seven soil samples with a different degree of contamination were studied using a randomized experimental design, with four replicates. By using an ICP-OES we analyzed the concentrations of $\mathrm{Cu}$ and $\mathrm{Zn}$ in the diagnostic leafs, at the end of the cycle (LCE) and several of its content in the soil: available extracted with the DTPA, Mehlich-1 and HCl extractants, soluble+exchangeable contents, bound to organic matter, to oxides and the total content. For both, soybean and rice, the concentrations of $\mathrm{Cu}$ and $\mathrm{Zn}$ extracted from the sequential extraction was found to be correlated with the concentration in LCE. For soybean, Zn concentration extracted with DTPA was correlated with the total concentration, while $\mathrm{Cu}$ concentration extracted with three extractors, DTPA, Mehlich-1 and $\mathrm{HCl}$, correlated with the total concentration, probably due to the high concentration of $\mathrm{Cu}$ and $\mathrm{Zn}$ in this soil. For rice, both $\mathrm{Cu}$ and $\mathrm{Zn}$ concentration as extracted by the three extracting solutions correlated with the concentration of all the fractions and with the total concentration
\end{abstract}

Key words: DTPA, HCl, crops, Mehlich-1, sequential extraction

\section{QUANTIFICAÇÃO DE COBRE E ZINCO AVALIADOS POR EXTRATORES QUIIMICOS EM SOLO CONTAMINADO}

RESUMO: Os elementos traços são potencialmente tóxicos para o meio ambiente. Estas toxicidades dependem de suas associações químicas. Por isso a determinação da forma química destes elementos no solo é importante para quantificá-lo. O objetivo do presente trabalho foi avaliar a possibilidade de se utilizar teores de $\mathrm{Cu}$ e $\mathrm{Zn}$ nas diferentes frações do solo para prognosticar suas disponibilidades. Para isso, compararam-se as mesmas com soluções extratoras clássicas, como DTPA, Mehlich-1 e HCl, e com teores absorvidos por plantas de arroz e soja em materiais de solos contaminados. Foram estudadas sete amostras de solos com diferentes graus de contaminação empregando delineamento experimental inteiramente casualizado, com quatro repetições. Utilizando a técnica de ICP-OES, foram avaliados teores de $\mathrm{Cu}$ e $\mathrm{Zn}$ em folha diagnóstico e folha em final de ciclo (LCE) e no solo: teores disponíveis utilizando as soluções extratoras DTPA, Mehlich-1 e $\mathrm{HCl}$, teores nas frações de solo solúvel+trocável, ligados à matéria orgânica e ligados a óxidos e o teor total. Para a soja e arroz, os teores de Cu e Zn extraídos do fracionamento correlacionaram significativamente com os teores obtidos na LCE. Para a soja, os teores de Zn extraídos com DTPA apresentaram alta correlação com os teores totais, enquanto que os teores de Cu extraídos pelos três extratores, DTPA, Mehlich-1 e HCl, correlacionaram com o teor total, provavelmente devido aos altos teores de $\mathrm{Cu}$ e $\mathrm{Zn}$ neste solo. Para o arroz, os teores de $\mathrm{Cu}$ e $\mathrm{Zn}$ extraídos pelas três soluções correlacionaram com teores em todas as frações e com o teor total.

Palavras-chave: DTPA, HCl, culturas, Mehlich-1, extração seqüencial 


\section{INTRODUCTION}

Soil contamination by trace elements is a problem frequently observed in developing countries (Mendes et al., 2006). Contaminated soils can hinder the development of many plant, species as well as soil microorganisms (Paiva et al., 2002).

Trace elements in soils may be parted according to their geochemical forms, which can be selectively extracted using proper reagents. Each method employs a group of reagents that should specifically interact with the geochemical forms (Tessier et al., 1979; Amaral Sobrinho et al., 1997). The information thus gained will be useful for the evaluation of the phytoavailability, phytotoxicity, dynamics and transformations of the trace elements among their chemical forms as found in contaminated soils (Costa et al., 2002). The sequential extraction (SE) methods have been used in order to identify the structures in which those elements are associated (Amaral Sobrinho et al., 1997).

In spite of the long time required to perform a $\mathrm{SE}$, these methods have the advantage of being useful to make inferences on the origin, occurrence forms, bioavailability, flow, mobility and transport of trace elements (Tessier et al., 1979). By the use of SE methods it is possible to detect the trace elements both in their relatively more labile chemical forms (soluble, exchangeable and linked to the carbonates), and in their more stable forms and also the ones with smaller mobility and/ or bioavailability (linked to oxides of Fe or of Mn, linked to the organic matter of the soil; Silva, 1999a).
The availability of trace elements can be evaluated by means of chemical extraction followed by correlation analysis with the amount of the element accumulated (or concentrated) in the plant tissues (Abreu et al., 2002).

Complexant agents allow removing elements linked to organic radicals and carbonates, easily extracting the labile forms without dissolving the nonlabile (Abreu et al., 1997). Acid extractors extract amounts close to the total due to their dissolving power of the mineral structures retaining trace elements in the soil (Taylor et al., 1993; Roca \& Pomares, 1991). Among the extractors normally used to study the phytodisponibility, stands out the complexant DTPA and the acid solutions $\mathrm{HCl} 0.1 \mathrm{~mol} \mathrm{~L}^{-1}$ and Mehlich-1 (Anjos \& Mattiazzo, 2001; Oliveira, 2000).

The objective the present work was to evaluate the possibility of using the concentrations of $\mathrm{Cu}$ and $\mathrm{Zn}$ in different soil fractions and their total concentration in the soil as predictors of their quantification by comparing them with classical extractors and with the concentrations absorved by rice and soybean in contaminated soil.

\section{MATERIALAND METHODS}

The soil used had been accidentally contaminated presenting high levels of trace elements (Table 1). Samples of a Typic Hapludox were colleted in Paulínia, São Paulo state, Brazil (2245’ S, 4709’ W) (Table 2). Samples were taken at a $0-20 \mathrm{~cm}$ depth in

Table 1- Chemical characterization of the soil samples.

\begin{tabular}{|c|c|c|c|c|c|c|c|c|}
\hline \multirow[b]{2}{*}{ Determination } & \multirow[b]{2}{*}{ Unit } & \multicolumn{7}{|c|}{ Value } \\
\hline & & $\begin{array}{c}\text { Sample } \\
1\end{array}$ & $\begin{array}{c}\text { Sample } \\
2\end{array}$ & $\begin{array}{c}\text { Sample } \\
3\end{array}$ & $\begin{array}{c}\text { Sample } \\
4\end{array}$ & $\begin{array}{c}\text { Sample } \\
5\end{array}$ & $\begin{array}{c}\text { Sample } \\
6\end{array}$ & $\begin{array}{c}\text { Sample } \\
7\end{array}$ \\
\hline${ }^{(1)} \mathrm{pH}\left(\mathrm{CaCl}_{2} 0,01 \mathrm{~mol} \mathrm{~L}^{-1}\right)$ & & 5.2 & 5.3 & 5.5 & 5.5 & 5.2 & 5.8 & 5.8 \\
\hline${ }^{(1,3)}$ Organic matter & $\mathrm{g} \mathrm{dm}^{-3}$ & 3.4 & 3.6 & 3.5 & 3.7 & 3.4 & 3.6 & 3.0 \\
\hline${ }^{(1,4)}$ Phosphorus & $\mathrm{g} \mathrm{dm}^{-3}$ & 17.5 & 20.8 & 21.5 & 22.1 & 56.1 & 36.0 & 59.1 \\
\hline${ }^{(1,4)}$ Potassium & $\mathrm{mmol}_{\mathrm{c}} \mathrm{dm}^{-3}$ & 8.7 & 7.4 & 11.3 & 11.8 & 5.4 & 14.1 & 12.0 \\
\hline${ }^{(1,4)}$ Calcium & $\mathrm{mmol}_{\mathrm{c}} \mathrm{dm}^{-3}$ & 17 & 36 & 36 & 41 & 38 & 33 & 44 \\
\hline${ }^{(1,4)}$ Magnesium & $\mathrm{mmol}_{\mathrm{c}} \mathrm{dm}^{-3}$ & 5 & 16 & 20 & 24 & 20 & 19 & 8 \\
\hline${ }^{(1,5)} \mathrm{H}+\mathrm{Al}$ & $\mathrm{mmol}_{\mathrm{c}} \mathrm{dm}^{-3}$ & 61 & 31 & 29 & 29 & 36 & 26 & 24 \\
\hline Sum of bases & $\mathrm{mmol}_{\mathrm{c}} \mathrm{dm}^{-3}$ & 30.7 & 59.4 & 67.3 & 76.8 & 63.4 & 66.1 & 64.0 \\
\hline Total CEC & $\mathrm{mmol}_{\mathrm{c}} \mathrm{dm}^{-3}$ & 91.7 & 90.4 & 96.3 & 105.8 & 99.4 & 92.1 & 88.0 \\
\hline V (base saturation) & $\%$ & 33.5 & 65.7 & 69.9 & 72.6 & 63.8 & 71.8 & 72.7 \\
\hline${ }^{(1,6)}$ Availability Copper & $\mathrm{mg} \mathrm{dm^{-3 }}$ & 11.7 & 13.4 & 11.4 & 9.3 & 12.3 & 18.8 & 77.0 \\
\hline${ }^{(1,6)}$ Availability Zinc & $\mathrm{mg} \mathrm{dm}{ }^{-3}$ & 3.5 & 6.7 & 9.3 & 14.4 & 28.1 & 62.5 & 255.8 \\
\hline (7)Total Copper & $\mathrm{mg} \mathrm{kg}{ }^{-1}$ & 153 & 166 & 144 & 121 & 115 & 141 & 272 \\
\hline${ }^{(7)}$ Total Zinc & $\mathrm{mg} \mathrm{kg}^{-1}$ & 102 & 108 & 106 & 106 & 113 & 189 & 554 \\
\hline
\end{tabular}


seven different points following a $100 \mathrm{~m}$ interval, starting from the source of pollution. They were air dried sieved $(5 \mathrm{~mm})$ and stored. Soil samples were placed in $5 \mathrm{dm}^{-3}$ capacity pots. Irrigation was done in a way not to exceed the maximum of $70 \%$ and minimum of $40 \%$ of the maximum water retention capacity, by daily weighting the pots.

The experiments were conducted in a greenhouse, in Piracicaba, SP, Brazil from November, 2004 to April, 2005. The plant species used were rice (Oriza sativa L. cv. IAC 202) and soybean (Glycine max L. cv. BRS 133). Fertilization with NPK was done according to each crop need A randomized experimental design was used, in a factorial scheme $7 \times 2$ (seven soil samples and two plants species), with four replicates, performing a total of 56 experimental units.

Ten seeds were sown in each pot on November 25, 2004, both for rice and soybeans. Germination began on the $28^{\text {th }}$ day. Plants were thinned to four per pot on December 11, 2004. The diagnostic leaves were collected following Malavolta et al. (1997). For rice, the leaf Y (immediately below the newest uncoiled leaf) was collected in the middle of the tilling period, 50 days after sowing. For soybean, the first ripe leaf starting from the tip of the branch was collected, at the end of the flowering period (on the $69^{\text {th }}$ day after sowing). The samples were stored in paper bags and dried. Thereafter, the plants were grown until maturation and cut close to the soil surface. The colleted material was washed in running water and rinsed in distilled water. Afterwards, they were dried in an aerated stove (temperature maintained between $60-70^{\circ} \mathrm{C}$ ), weighed and crushed in a Wiley mill. Digestion was done in an open system, using a slight modification of the method described by Oliva et al. (2003).

The available concentrations of $\mathrm{Cu}$ and $\mathrm{Zn}$ in soil samples were extracted by solutions of Mehlich1 ( $\mathrm{HCl} 0.05 \mathrm{~mol} \mathrm{~L}^{-1}+\mathrm{H}_{2} \mathrm{SO}_{4} 0.0125 \mathrm{~mol} \mathrm{~L}^{-1}$; Silva, 1999b), HCl $0.1 \mathrm{~mol} \mathrm{~L}^{-1}$ (Wear \& Sommer, 1947) and DTPA at pH 7.3 (Lindsay \& Norvell, 1978).

The sequential extraction for $\mathrm{Cu}$ and $\mathrm{Zn}$ in each soil fraction after plant cultivation was performed according to Ahnstrom \& Parker (1999), ex-

Table 2 - Particle size, iron and aluminum oxides content in the studied soil.

\begin{tabular}{lcc}
\hline${ }^{(1)}$ Determination & Unit & Value \\
\hline Clay & $\mathrm{g} \mathrm{kg}^{-1}$ & 590 \\
Silt & $\mathrm{g} \mathrm{kg}^{-1}$ & 100 \\
Sand & $\mathrm{g} \mathrm{kg}^{-1}$ & 310 \\
$\mathrm{Fe}_{2} \mathrm{O}_{3}$ & $\mathrm{~g} \mathrm{~kg}^{-1}$ & 126 \\
$\mathrm{Al}_{2} \mathrm{O}_{3}$ & $\mathrm{~g} \mathrm{~kg}^{-1}$ & 132 \\
\hline
\end{tabular}

${ }^{(1)}$ Camargo et al. (1986). cept for the carbonate phase, since carbonates is known to be present in very small concentrations in this soil. $2 \mathrm{~g}$ samples of were crushed in a porcelain mortar with the aim of mixing the components and make easy the extractors action. All extractions were carried out in $50 \mathrm{~mL}$ centrifuge tubes. To extract $\mathrm{Cu}$ and $\mathrm{Zn}$ from the fraction 1 (soluble + exchangeable (S/Ex)), $15 \mathrm{~mL}$ of $\mathrm{Sr}\left(\mathrm{NO}_{3}\right)_{2} 0.1 \mathrm{~mol} \mathrm{~L}^{-1}$ was added to the tubes, agitating it for $2 \mathrm{~h}$ at low speed. Afterwards, samples were centrifuged (2,500 rpm for 10 minutes). The supernatant was filtered (with quantitative blue strip paper) to $50 \mathrm{~mL}$ volumetric flasks. This procedure was repeated three times. For the extraction from fraction 2 (linked the organic matter $(\mathrm{OM})$ ), $5 \mathrm{~mL}$ of $5 \% \mathrm{NaOCl}$ was used (with $\mathrm{pH}$ adjusted to 8.5 with concentrated $\mathrm{HNO}_{3}$ ). Tubes were placed in a water bath $\left(90-95{ }^{\circ} \mathrm{C}\right)$ for 30 minutes under slow agitation. After this time, the samples were centrifuged $(2,500$ rpm during 10 minutes) and the supernatant filtered (quantitative blue strip paper) and collected in $50 \mathrm{~mL}$ volumetric flasks. This procedure was repeated until the organic matter was destroyed, that is, when foam was no longer present.

For the extraction from fraction 3 ( oxide tied $(\mathrm{Ox})$ ), $20 \mathrm{~mL}$ of a solution containing $0.2 \mathrm{~mol} \mathrm{~L}^{-1} \mathrm{ox}-$ alic acid $+0.2 \mathrm{~mol} \mathrm{~L}^{-1} \mathrm{NH}_{4}$ oxalate $+0.1 \mathrm{~mol} \mathrm{~L}^{-1}$ ascorbic acid (adjusted to $\mathrm{pH} 3.0$ with $\mathrm{NH}_{4} \mathrm{OH}$ ) was added. The tubes were placed in a water bath $\left(90-95^{\circ} \mathrm{C}\right)$ for 30 minutes under slow agitation. Afterwards, the samples were centrifuged (2,500 rpm for 10 minutes) and the supernatant was again filtered with quantitative blue strip paper filter and collected in $100 \mathrm{~mL}$ volumetric balloon. This procedure was repeated until the color of the soil turned gray (without iron) and the supernatant turned yellowish. At the end of each extraction phase (fractions 1, 2 and 3), the soil samples were washed with $5 \mathrm{~mL}$ of $\mathrm{NaCl} 0.1 \mathrm{~mol} \mathrm{~L}^{-1}$, centrifuged at 2,500 rpm for 10 minutes, and the supernatant added to the one already got from the respective fraction. Afterwards, $1 \mathrm{~mL}$ of concentrated $\mathrm{HNO}_{3}$ was added, and the volume was completed with distilled water to $50 \mathrm{~mL}, 50 \mathrm{~mL}$ and $100 \mathrm{~mL}$ for the extracts from the fractions 1, 2 and 3, respectively.

The extraction of the total $(\mathrm{T})$ concentration of $\mathrm{Cu}$ and $\mathrm{Zn}$ from the soil samples was done with aqua regia $\left(\mathrm{HCl} / \mathrm{HNO}_{3} 3: 1\right)$ in a microwave oven, according to Nieuwenhuize et al. (1991). The concentrations of $\mathrm{Cu}$ and $\mathrm{Zn}$ in the extracts were analyzed by an inductively coupled plasma optical emission spectrometer (ICP-OES).

The data on the concentration of $\mathrm{Cu}$ and $\mathrm{Zn}$ extracted form the fractions S/Ex, OM, Ox, and the $\mathrm{T}$ concentration were submitted to linear correlation analysis with the data obtained from the Mehlich-1, HCl 
$0.1 \mathrm{~mol} \mathrm{~L}^{-1}$ and DTPA, extraction methods, as well as with the data obtained from the extractions in the leaf diagnosis (DL) and in the leaf end of cycle (LCE) separately from both rice and soybean. The linear correlation was calculated using SAS for Windows version 6.12 (SAS, 1985).

\section{RESULTS AND DISCUSSION}

\section{Soybean}

The sequential extraction method has been used in an attempt to evaluate the relationship between the bioavailable fraction of the metal in the soil and the metal content in the plant (Zhang et al., 1998; Buanuam et al., 2005). The concentrations $\mathrm{Cu}$ and $\mathrm{Zn}$ extracted from the fraction $\mathrm{S} / \mathrm{Ex}$, linked to $\mathrm{OM}$ and $\mathrm{OX}$, and the $\mathrm{T}$ concentration were highly and positively correlated with the concentrations obtained in DL and LCE (Figures 1 and 2). Only the concentration S/Ex of Cu was not correlated with the concentration in LCE. Possibly, this was due to presence of $\mathrm{Zn}$ in high concentrations. High activities of $\mathrm{Zn}^{+2}$ in the soil solution may inhibit the $\mathrm{Cu}^{+2}$ uptake (Alloway, 1995). The T concentration in the soil is not considered to be a reliable parameter to predict phytoavailability (Zhang et al., 1998). However, it can be noticed in this study when the soil is contaminated with high concentrations of
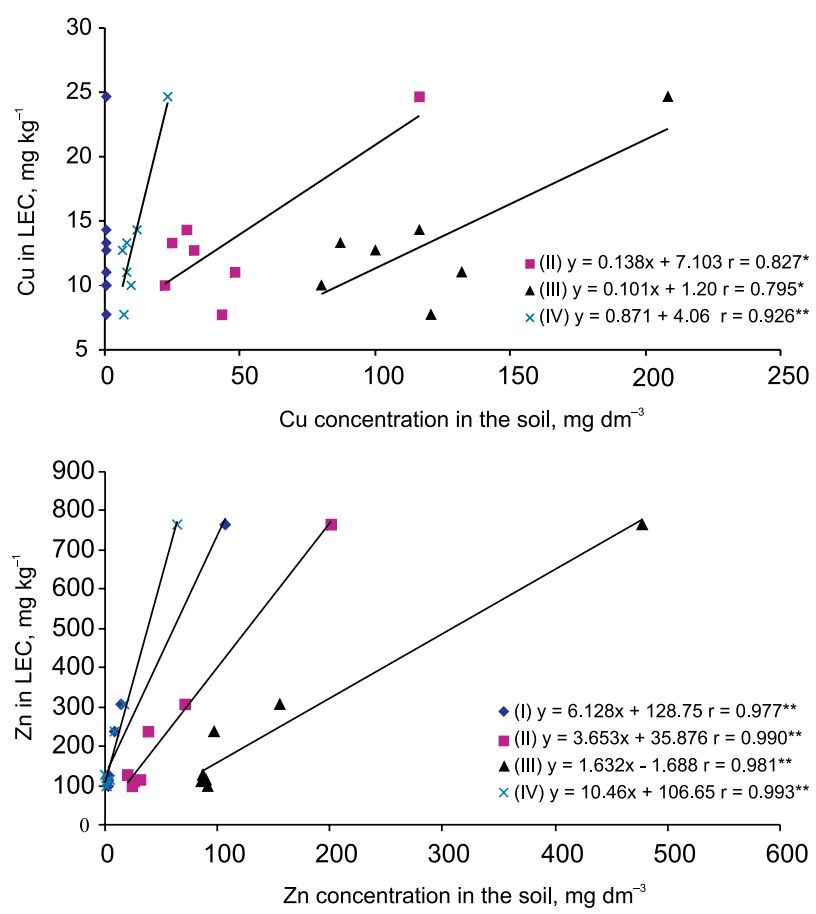

Figure 1 - Linear correlations among $\mathrm{Cu}$ and $\mathrm{Zn}$ concentrations in the leaves at the end of the cycle (LEC) of soybean and soluble/exchangeable concentrations (I), linked to oxides (II) total concentrations (III) and linked the organic matter (IV) (**significant to the $1 \%$; *significant to the $5 \%)$. trace elements, the total concentration is well correlated with the concentrations in plants (DL and LCE). Both $\mathrm{Cu}$ and $\mathrm{Zn}$ have high affinity for the organic matter. Gomes et al. (1997) reported that $\mathrm{Cu}$ reacts with the groups $\mathrm{COOH}$ and $\mathrm{OH}$ - phenol, simultaneously, forming highly stable chemical complexes.

The concentrations obtained in the sequential extraction (from the fractions S/Ex, linked to $\mathrm{OM}$ and $\mathrm{Ox}$ ) and the $\mathrm{T}$ concentration were highly correlated with the available concentrations extracted by the methods Mehlich-1, DTPA and HCl $0.1 \mathrm{~mol} \mathrm{~L}^{-1}$, both for $\mathrm{Cu}$ and $\mathrm{Zn}(p<0.01$; Figures 3 and 4$)$. Such a result can be explained by the elevated concentrations of $\mathrm{Cu}$ and $\mathrm{Zn}$ in the studied soil. It is possible that in a soil with low concentrations of $\mathrm{Cu}$ and $\mathrm{Zn}$, for example $0.8 \mathrm{mg} \mathrm{dm}^{-3}$ to $\mathrm{Cu}$ and $1.2 \mathrm{mg} \mathrm{dm}^{-3}$ to $\mathrm{Zn}$ extracts by DTPA (Raij et al., 1997), the same results will not be obtained. Zhang et al. (1998) did not obtain significant correlations among the concentrations uptake by the plants and the concentrations obtained in the fractions in soils with standard concentrations of $\mathrm{Cu}$ and $\mathrm{Zn}$.

The acid extractors such as Mehlich- 1 and $\mathrm{HCl}$ $0.1 \mathrm{~mol} \mathrm{~L}^{-1}$ extract the trace elements mainly by dissolving the clay minerals. The amount extracted will depend on the acid solution concentration, on the time of extraction and on the solution/soil ratio. The acids extract amounts close to the total concentration due
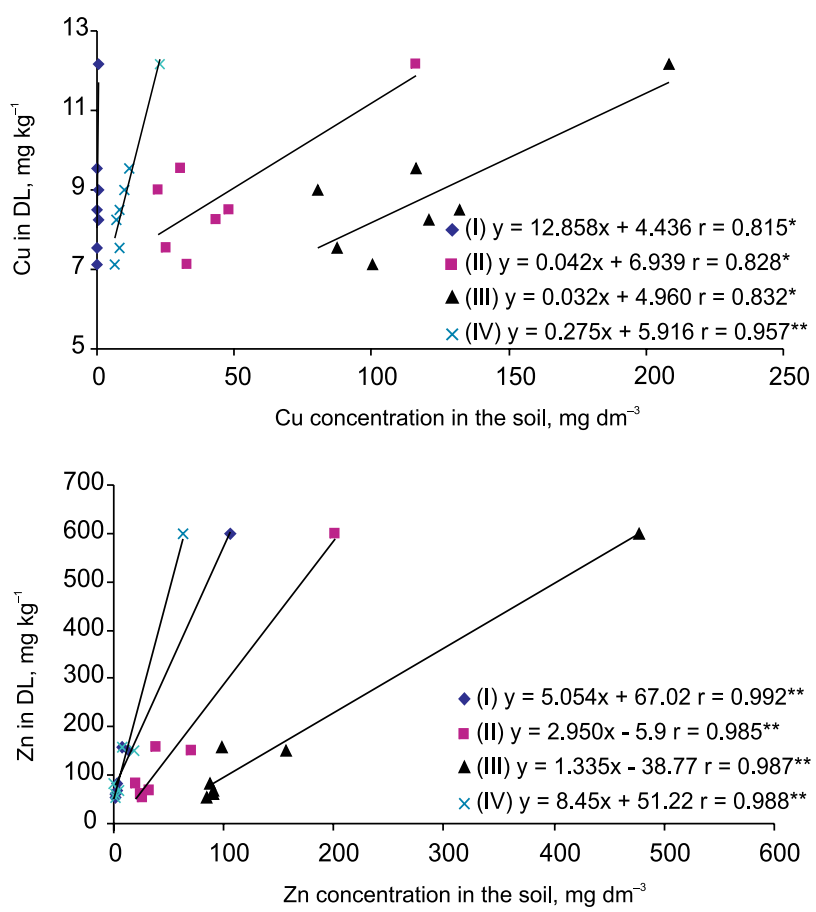

Figure 2 - Linear correlations among $\mathrm{Cu}$ and $\mathrm{Zn}$ concentrations in the diagnostic leaf (DL) of soybean and soluble/ exchangeable concentrations(I), linked to oxides (II), total concentrations (III) and linked the organic matter (IV) $(* *$ significant to the $1 \%$; *significant to the $5 \%$ ). 

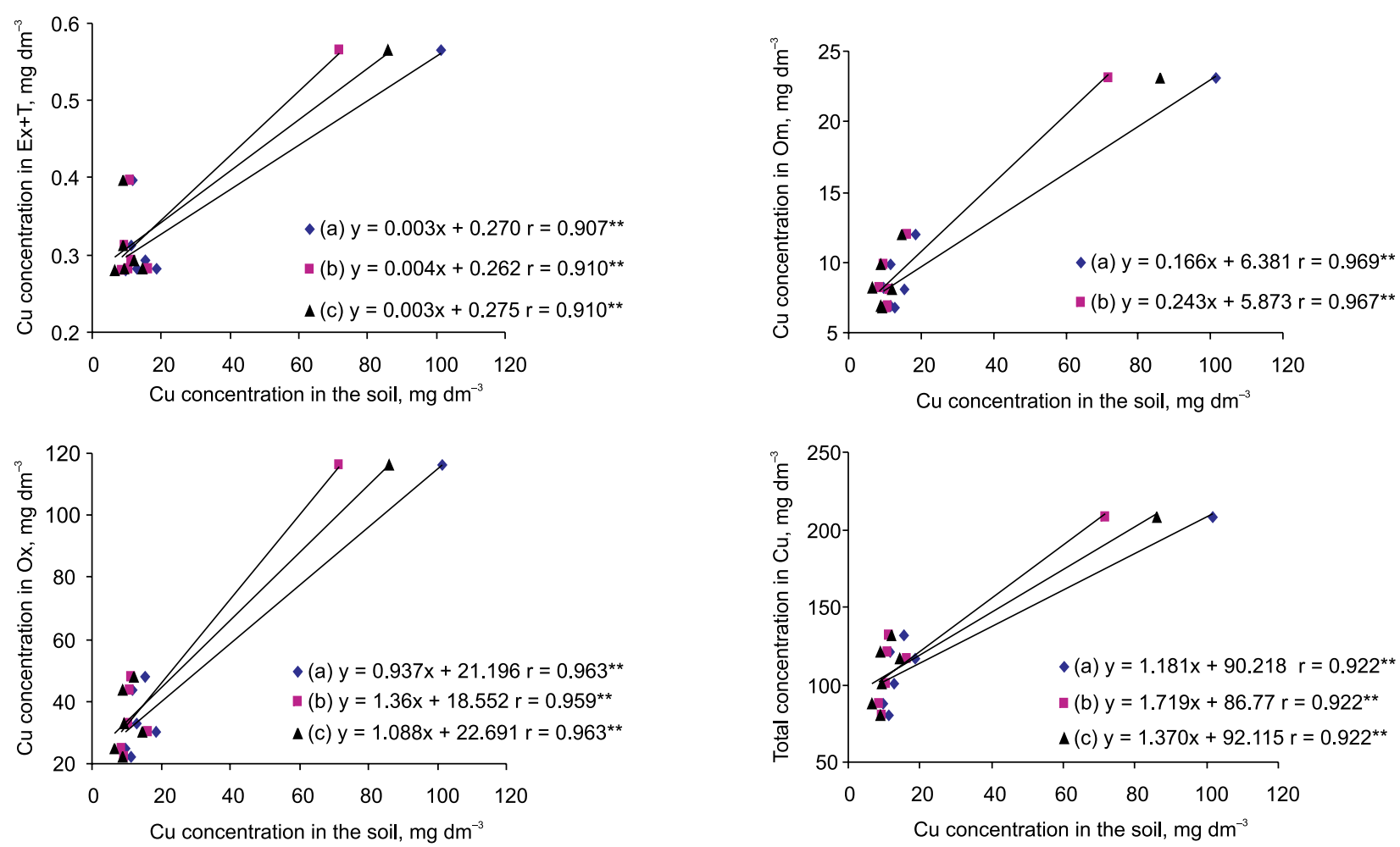

Figure 3 - Linear correlations among soluble/exchangeable concentrations (S/Ex), linked the organic matter (OM), linked to oxides (Ox) and total concentrations (T) and extracted available concentrations for the solutions Mehlich-1 (a), DTPA (b) and HCl 0.1 mol $\mathrm{L}^{-1}(\mathrm{c})$, after the cultivation of soybean (**significant to the $1 \%$; *significant to the $5 \%$ ).
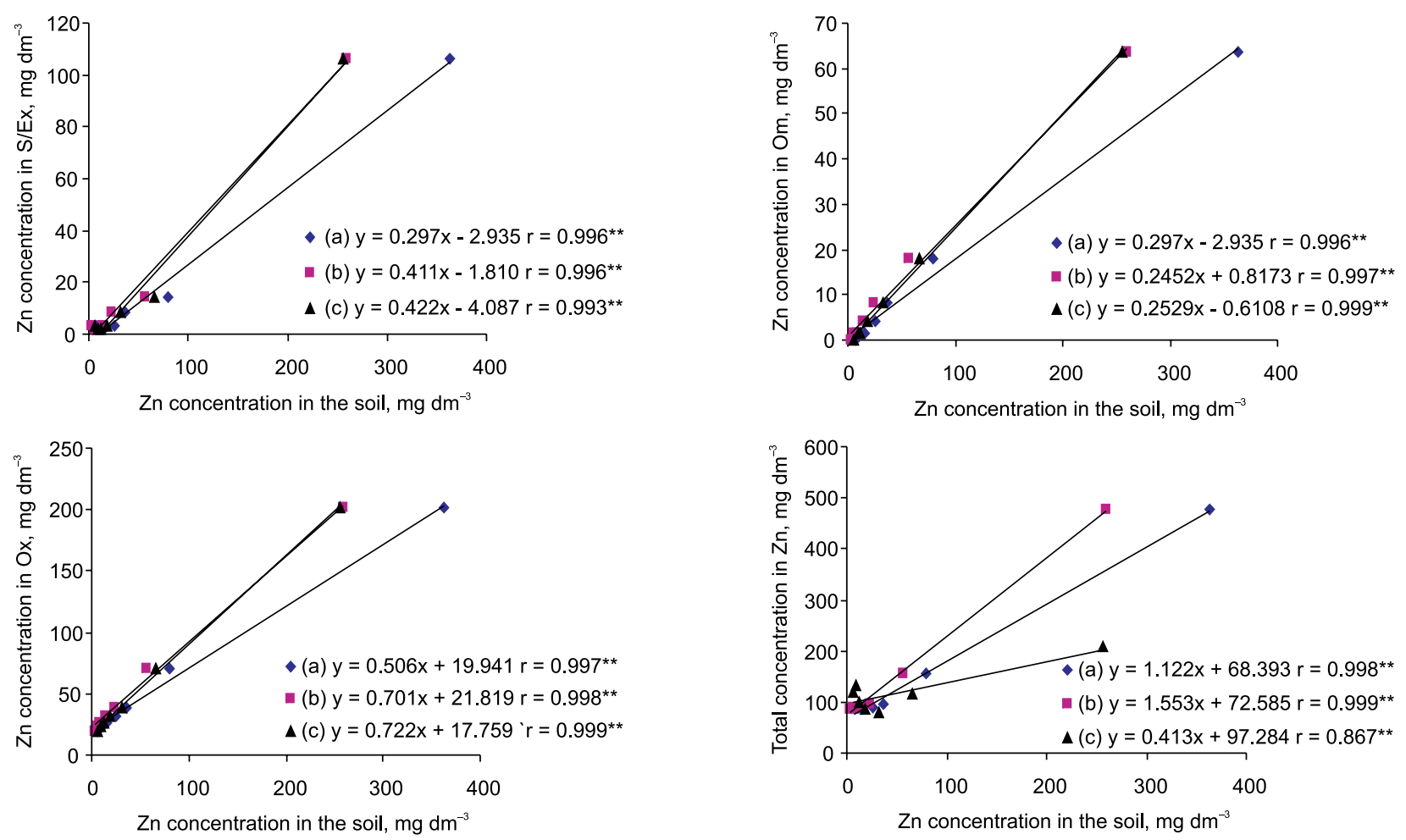

Figure 4 - Linear correlations among soluble/exchangeable concentrations (S/Ex), linked the organic matter (OM), linked to oxides (Ox) and total concentrations ( $\mathrm{T}$ ) and extracted available concentrations for the solutions Mehlich-1 (a), DTPA (b) and HCl 0.1 mol $\mathrm{L}^{-1}(\mathrm{c})$, after the cultivation of soybean (**significant to the $1 \%$; *significant to the $\left.5 \%\right)$. 
to their dissolving power, (even when partially) (Taylor et al., 1993; Roca \& Pomares, 1991). Chelant solutions act by combining with metallic ions thereby forming soluble complexes, and reducing the ionic activity in soil solution. Consequently, the ions are desorbed from the surface of the soil solids to reestablish the solution ionic equilibrium (Abreu et al., 2002). Ure (1991) considers that the sequential extraction acts in the soil through chemical reagents, or solvents, denominated extractors, specifically to extract elements linked or associated with the clay fraction. Perhaps, for that reason, there was a positive correlation among the concentrations obtained for the fractions of the soil with the obtained with the extractors, Mehlich-1 and $\mathrm{HCl} 0.1 \mathrm{~mol} \mathrm{~L}^{-1}$ (acids) and DTPA (chelating agents).

\section{Rice}

The concentration of $\mathrm{Cu}$ and $\mathrm{Zn}$ in LCE were correlated to the ones extracted by the sequential extraction method (Figure 5), except for $\mathrm{Cu}$ extracted from the S/Ex fraction. Such correlation was not obtained being probably influenced by $\mathrm{Zn}$ concentrations in the soil or unavailable forms of $\mathrm{Cu}$ in the soil. The amount of metals absorbed is affected by many factors and it is difficult to determine the relationship between plant uptake and the metal fractions in the soil with simple correlation analysis (Zhang et al., 1998). $\mathrm{Cu}$ concentrations in DL were correlated only with the
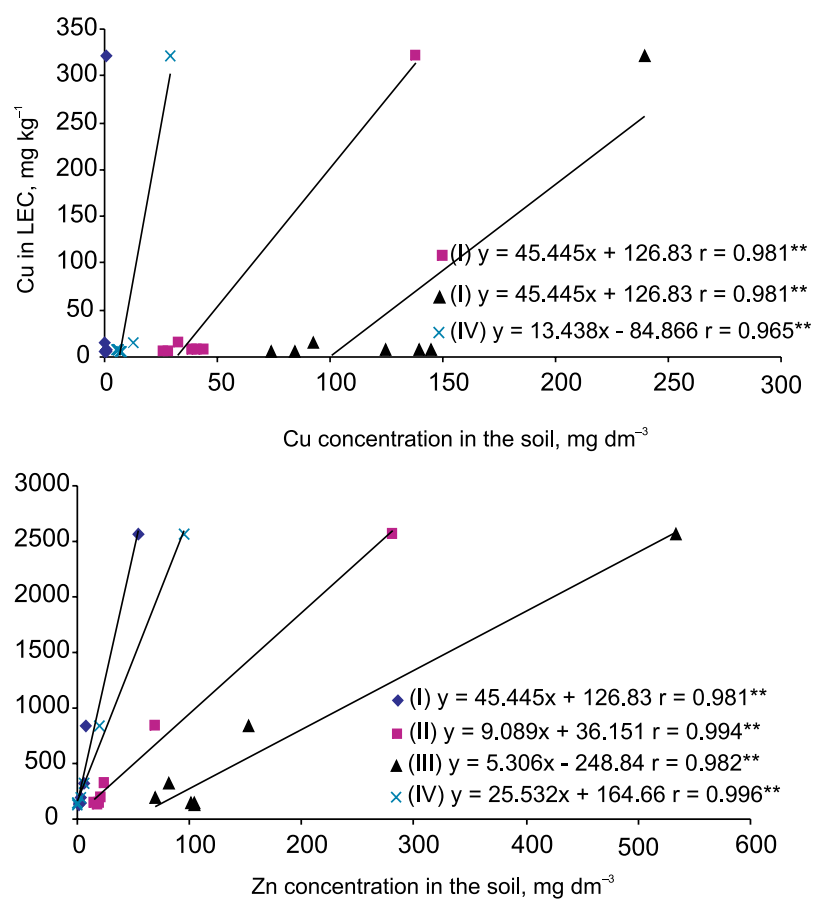

Figure 5 - Linear correlations among $\mathrm{Cu}$ and $\mathrm{Zn}$ concentrations in the leaves at the end (LEC) of the rice cycle and soluble/ exchangeable concentrations (I), linked to oxides (II), total concentrations (III) and linked the organic matter (IV) ${ }^{* *}$ significant to the $1 \%$; *significant to the $\left.5 \%\right)$. concentration obtained in OM. Zn concentration in DL were significantly correlated with the concentrations obtained from all the fractions, but not with $\mathrm{T}$ concentration (Figure 6). Perhaps the adsorption is the main process to be considered to understand the availability of $\mathrm{Cu}$ and $\mathrm{Zn}$, being indicative of the solubility and mobility of those elements and the consequent availability for the plants (Nascimento \& Fontes, 2004).

Zhang et al. (1998) correlating the concentrations of $\mathrm{Cu}$ and $\mathrm{Zn}$ obtained in the different parts of the corn with the concentrations of $\mathrm{Cu}$ and $\mathrm{Zn}$ in the fractions of the soil (exchangeable, bound to oxide or organic matter) did not obtain significant correlation. The concentrations of $\mathrm{Zn}$ in the corn roots presented significant correlation with the fraction bound to oxides of Fe-Mn.

Usually, the total amount of trace elements is a parameter used for to control soil pollution (Camargo et al., 2000). As already mentioned, the $\mathrm{T}$ concentration of traces elements in the soil is not a reliable parameter to express their plant availability. Contrary to what was observed for soybean, there was no correlation between the concentrations in DL and $\mathrm{T}$ for rice. Obata (1995) observed $\mathrm{Cu}$ concentrations in rice from 5 to $20 \mathrm{mg} \mathrm{kg}^{-1}$. The excess of $\mathrm{Cu}$ in the soil cause damage to the plant only when the soluble concentration of this element goes beyond $125 \mathrm{mg} \mathrm{dm}^{-3}$. For $\mathrm{Zn}$, the normal concentration in rice varies from 30
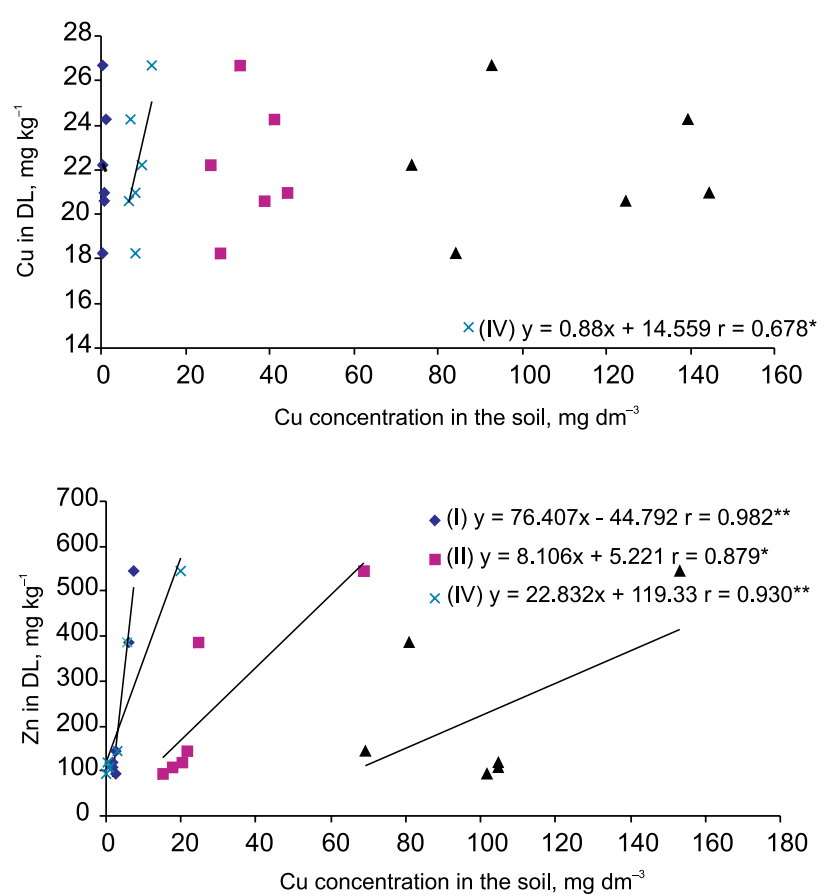

Figure 6 - Linear correlations among $\mathrm{Cu}$ and $\mathrm{Zn}$ concentrations in the diagnostic leaf (DL) of rice and soluble/exchangeable concentrations (I), linked to oxides (II), total concentrations (III) and linked the organic matter (IV) (**significant to the $1 \%$; *significant to the $5 \%$ ). 
to $100 \mathrm{mg} \mathrm{kg}^{-1}$, indicating that this species is relatively tolerant to its excess (Obata, 1995). If toxicity occurs, it appears in the form of a decrease in the height of the plant and in the tiller number (Obata, 1995).

The absorption of $\mathrm{Cu}$ by the plants do not correlate very well with the concentrations of $\mathrm{Cu}$ in the
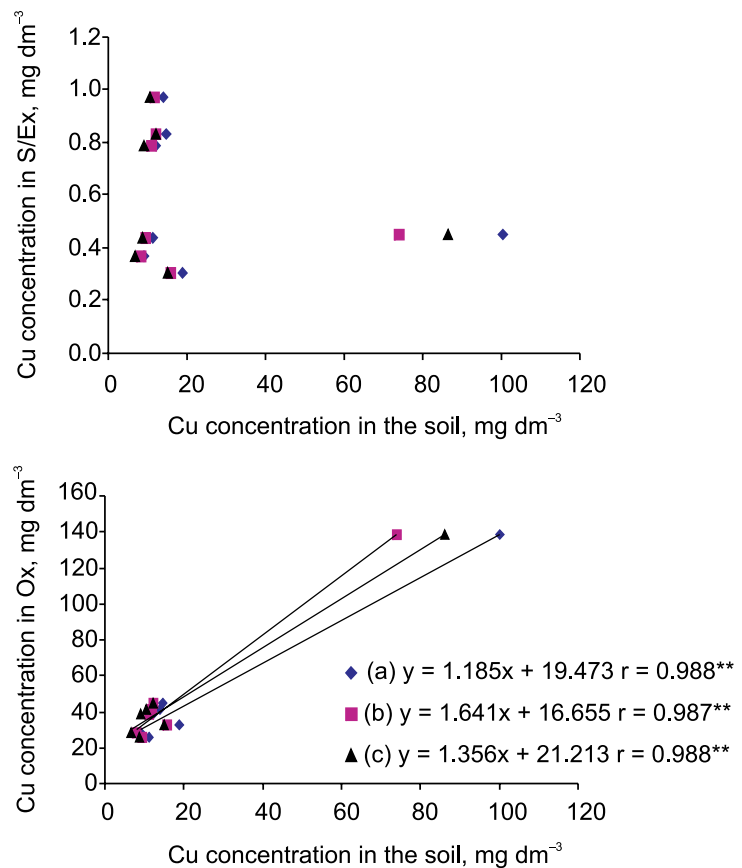

soil and/or with amounts extracted by the several extractors due to its inconstant chemical activity in soil solutions (Alloway, 1995). Both for $\mathrm{Cu}$ and $\mathrm{Zn}$ the "available" concentrations extracted by Mehlich-1, HCl and DTPA had highly significant correlations $(p<0.01)$ with the concentrations extracted by sequential extrac-
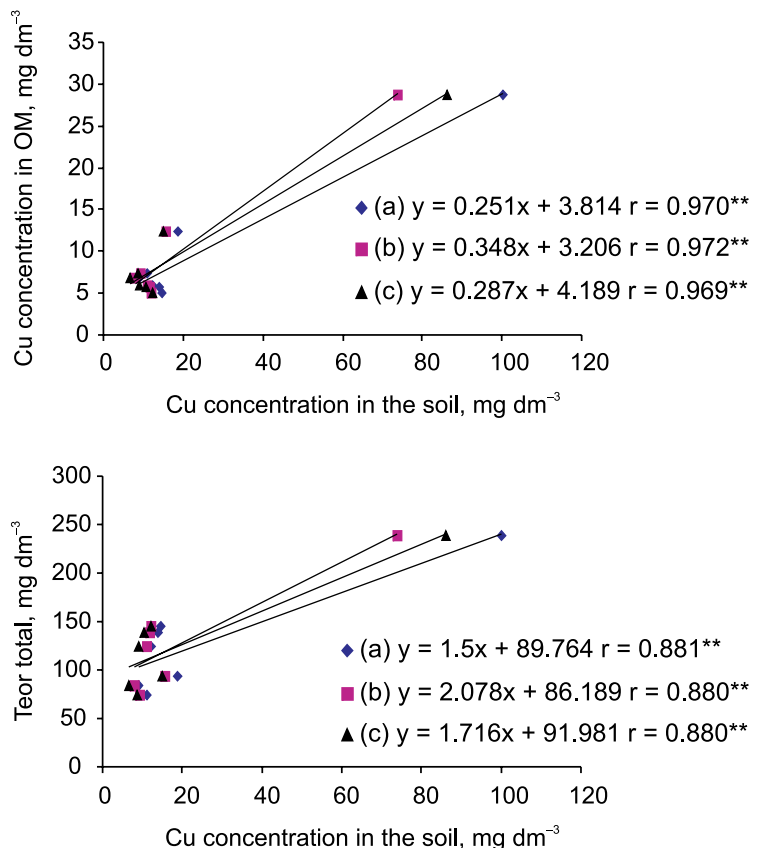

Figure 7 - Linear correlations among soluble/exchangeable concentrations (S/Ex), linked the organic matter (OM), linked to oxides (Ox) and total concentrations (T) and extracted available concentrations for the solutions Mehlich-1 (a), DTPA (b) and HCl 0.1mol $\mathrm{L}^{-1}$ (c), after the cultivation of rice (**significant to the $1 \%$; *significant to the $5 \%$ ).
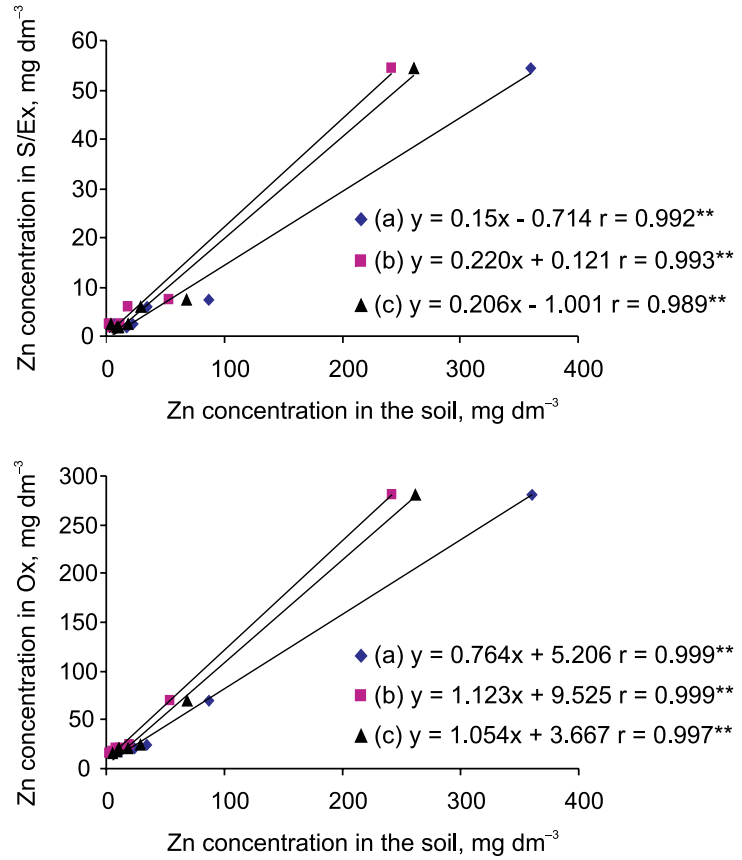
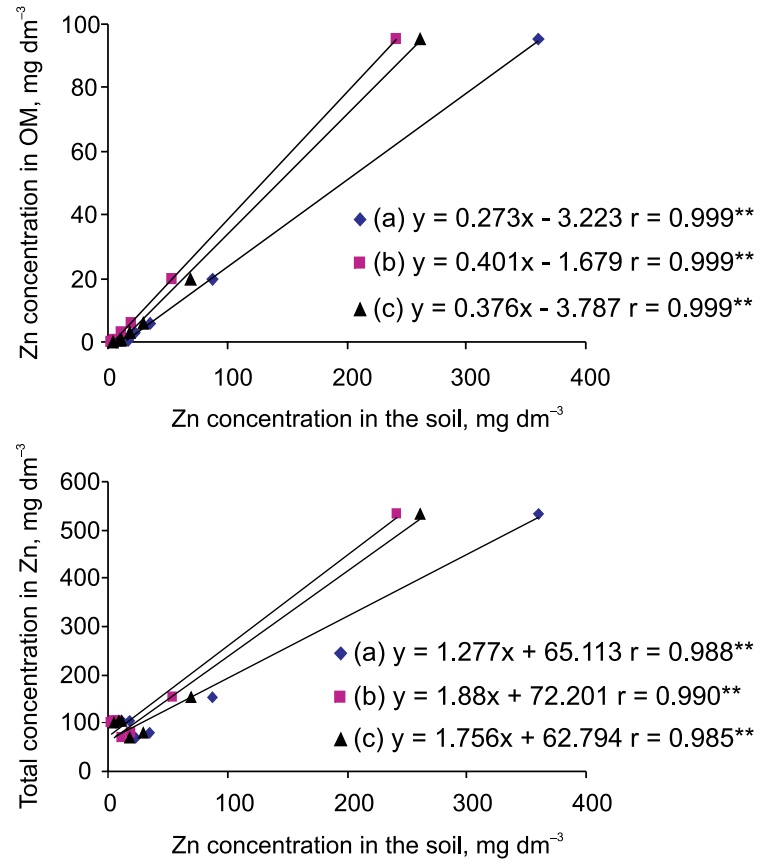

Figure 8 - Linear correlations among soluble/exchangeable concentrations (S/Ex), linked the organic matter (OM), linked to oxides (Ox) and total concentrations (T) and extracted available concentrations for the solutions Mehlich-1 (a), DTPA (b) and HCl 0.1mol $\mathrm{L}^{-1}(\mathrm{c})$, after the cultivation of rice (**significant to the $1 \%$; *significant to the $\left.5 \%\right)$. 
tors in all the fractions ( $\mathrm{S} / \mathrm{EX}$, linked to $\mathrm{OM}$ and $\mathrm{Ox}$ ) and the $\mathrm{T}$ concentration, except for the $\mathrm{Cu}$ concentration from the S/Ex fraction (Figures 7 and 8).

A great number of factors influence the availability and sorption of trace elements in the soil, such as the characteristics of the colloids (clay minerals, oxides and organic matter), $\mathrm{pH}$, ionic concentration of the solution, presence of cations and organic and inorganic ligands (Ross, 1994). Considering that in this study the soil has high concentrations of $\mathrm{Cu}$ and $\mathrm{Zn}$, it is plausible that concentrations linked to Ox, the $\mathrm{T}$ concentrations correlated with the "available" concentrations extracted by the solutions, since great part of $\mathrm{Cu}$ and $\mathrm{Zn}$ is soluble or quickly available in the soil. Furthermore, the concentrations of $\mathrm{Zn}$ accessed by the extractors Mehlich-1, DTPA and HCl $0.1 \mathrm{~mol} \mathrm{~L}^{-1}$ had highly significant correlations with the concentrations in the fractions S/EX and linked to $\mathrm{OM}$, which are potential reservoirs of those elements for the plants. These extractors possess appropriate capacity of extraction of the most available forms (Shuman, 1988). Trace elements linked to Ox are not available to plants (Shuman, 1988). However, when a soil exhibits high levels of trace elements, this could not be observed, probably because the reactions of adsorption-desorption tend to be faster, caused by the competition among ions for the surfaces adsorbents (Harter, 1991).

In trace elements bioavailability studies of contaminated soil, is generally accepted that trace elements bioavailability in soils depends on many factors. These factors are not completely understood and simple relationships are seldom found in natural soil systems between the plant trace elements levels and the total amount of the trace elements concentrations in soil. In some investigations, correlations between specific trace elements fractions and plant trace elements contents were found. For example, in soils that had been amended with composted or liquid sewage sludge it was found that $\mathrm{Zn}$ in exchangeable and oxide fractions had a strong correlation with $\mathrm{Zn}$ in the leaves of barley (Hordeum vulgar). A simple relationship existed between Co in the exchangeable fraction and the Co concentration in winter wheat (Triticum aestivum L.) and alfalfa (Medicago sativa L.) while the adsorption of $\mathrm{Ni}, \mathrm{Cu}$ and $\mathrm{Pb}$ by plants could be predicted by a stepwise multiple regression procedure. These studies show the possibility for using sequential extraction data to evaluate the correlation between trace elements in soil and plant uptake. Therefore, the relationship between plant uptake of trace elements and the trace elements concentration in some fractions was also investigated (Buanuam et al., 2005).

\section{CONCLUSIONS}

For the soybean, both $\mathrm{Cu}$ and $\mathrm{Zn}$ concentrations in LCE and DL are derived from the fractions bound to the OM, to Ox and the T contents. However, for rice, Zn concentrations in LCE and DL seems to be derived from the S/Ex, OM and Ox fractions, while $\mathrm{Cu}$ concentration in LEC were derived from the $\mathrm{OM}$, Ox fractions and $\mathrm{T}$ contents.

The DTPA, HCl $0.1 \mathrm{~mol} \mathrm{~L}^{-1}$ and Mehlich-1 extractors, under this soil condition, after the cultivation of both cultures, extracted $\mathrm{Cu}$ and $\mathrm{Zn}$ from the $\mathrm{OM}$, Ox fractions and $\mathrm{T}$ concentration.

\section{REFERENCES}

ABREU, C.A.; ABREU, M.F.; SOARES, L.H.; ANDRADE, J.C. The effects of the DTPA extraction conditions on the determination of micronutrients in Brazilian soils. Communications in Soil Science and Plant Analysis, v.28, p.1-11, 1997.

ABREU, C.A.; ABREU, M.F.; BERTON, R.S. Análise química de solos para metais pesados. Tópicos Ciência do Solo, v.2, p.148, 2002.

ABREU, C.A.; ANDRADE, J.C. Determinação de cobre, ferro, manganês, zinco, cádmio, cromo, níquel e chumbo em solos usando a solução de DTPA em pH 7,3. In: RAIJ, B. van; ANDRADE, J.C.; CANTARELLA, H.; QUAGGIO, J.A. (Ed.) Análise química para avaliação da fertilidade de solos tropicais. Campinas: Instituto Agronômico, 2001. cap.16, p.240-250

AHNSTROM, Z.S.; PARKER, D.R. Development and assessment of a sequential extraction procedure for the fractionation of soil cadmium. Soil Science Society of America Journal, v.63, p.1650-1658, 1999.

ALLOWAY, B.J. Heavy metals in soils. 2 ed. London: Blackie Academic \& Professional, 1995. 368p.

AMARAL SOBRINHO, N.M.B.; VELLOSO, A.C.X.; OLIVEIRA, C. Solubilidade de metais pesados em solo tratado com resíduo siderúrgico. Revista Brasileira de Ciência do Solo, v.21, p.9-16, 1997.

ANJOS, A.R.M.; MATTIAZZO, M.E. Extratores para Cd, $\mathrm{Cu}, \mathrm{Cr}$, $\mathrm{Mn}, \mathrm{Ni}, \mathrm{Pb}$ e $\mathrm{Zn}$ em Latossolos tratados com biossólido e cultivados com milho. Scientia Agricola, v.58, p.337-344, 2001.

BUANUAM, J.; SHIOWATANA, J.; PONGSAKUL, P. Fractionation and elemental association of $\mathrm{Zn}, \mathrm{Cd}$ and $\mathrm{Pb}$ in soils contaminated by $\mathrm{Zn}$ minings using a continuous-flow sequential extraction. Journal of Environmental Monitoring, v.7, p.778-784, 2005.

CAMARGO, O.A.; MONIZ, A.C.; JORGE, J.A.; VALADARES, J.M.S. Métodos de análise química, mineralógica e física de solos do Instituto Agronômico. Campinas: Instituto Agronômico, 1986. 94p.

CAMARGO, M.S.; ANJOS, A.R.M.; ROSSI, C.; MALAVOLTA, E. Adubação fosfatada e metais pesados em latossolo cultivado com arroz. Scientia Agricola, v.57, p.513-518, 2000.

COSTA, A.C.S.; ALMEIDA, V.C.; LENZI, E.; NOVAKI, J. Determinação de cobre, alumínio e ferro em solos derivados do basalto através de extrações seqüenciais. Química Nova, v.25, p.548-552, 2002.

GOMES, P.C.; FONTES, M.P.F.; COSTA, L.M.; MENDONÇA, E.S. Extração fracionada de metais pesados em Latossolo vermelhoamarelo. Revista Brasileira de Ciência do Solo, v.21, p.543551, 1997. 
HARTER, R.D. Micronutrient adsorption-desorption reactions in soils. In: MORTVERDT, J.J.; COX, F.R.; SHUMAN, L.M.; WELCH, R.M. (Ed.) Micronutrients in the agriculture. Madison: Soil Science Society of America, 1991. p.59-88.

LINDSAY, W.L.; NORVELL, W.A. Development of a DTPA soil test for zinc, iron, manganese and copper. Soil Science Society of American Journal, v.42, p.421-428, 1978.

MALAVOLTA, E.; VITTI, G.C.; OLIVEIRA, S.A. Avaliação do estado nutricional das plantas: princípios e aplicações. 2 ed. Piracicaba: POTAFOS, 1997. 319p.

MENDES, A.M.S.; DUDA, G.P.; NASCIMENTO, C.W.A.; SILVA, M.O. Bioavailability of cadmium and lead in a soil amended with phosphorus fertilizers. Scientia Agricola, v.63, p.328332, 2006.

NASCIMENTO, C.W.A; FONTES, R.L.F. Correlação entre características de Latossolos e parâmetros de equações de adsorção de cobre e zinco. Revista Brasileira de Ciencia do Solo, v.28, p.965-971, 2004.

NIEUWENHUIZE, J.; POLEY-VOS, C.H.; AKKER, A.H. van den; DELFT, W. van. Comparison of microwave and conventional extraction techniques for the determinations of metals in soil, sediment and sludge sample by atomic spectrometry. The Analyst, v.116, p.347-351, 1991.

OBATA, H. Micro essential elements. In: MATSUO, T.; KUMAZAWA, K.; ISHII, R.; ISHIHARA, K.; HIRATA, H. (Ed.) Science of the rice plant. Tokyo: Food and Agriculture Policy Research Center, 1995. cap.2, p.420-433.

OLIVA, S.R.; RAITIO, H.; MINGORANCE, M.D. Comparison of two wet digestion procedures for multi-element analysis of plant samples. Communications in Soil Science and Plant Analysis, v.34, p.2913-2923, 2003.

OLIVEIRA, F.C. Disposição de lodo de esgoto e composto de lixo num Latossolo Vermelho-amarelo cultivado com cana-de-açúcar. Piracicaba: USP/ESALQ, 2000. 247p. (Doutorado).

PAIVA, H.N.; CARVALHO, J.G.; SIQUEIRA, J.D.; CORRÊA, J.B.D. Teor, conteúdo e índice de translocação de nutrientes em mudas de cedro (Cedrela fissilis vell.) submetidas a doses crescentes de zinco. Ciência Florestal, v.13, p.1-10, 2002.

RAIJ, B. van; QUAGGIO, J.A.; CANTARELLA, H.; ABREU, C.A. Os métodos de análise química do sistema IAC de análise de solo no contexto nacional. In: RAIJ, B. van; ANDRADE, J.C.; CANTARella, H.; QUAGgiO, J.A. (Ed.) Análise química para avaliação da fertilidade de solos tropicais. Campinas: Instituto Agronômico, 2001. cap.17, p.251-261.
RAIJ, B. van; CANTARELA, H.; QUAGGIO, J.A.; FURLANI, A.M.C. (Ed.) Recomendações de adubação e calagem para o Estado de São Paulo. 2. ed. Campinas: Instituto Agronômico, 1997. 285p.

ROCA, J.; POMARES, F. Prediction of available heavy metals by six chemical extractants in a sewage sludge-amended soil. Communications in Soil Science and Plant Analysis, v.22, p.2119-2136, 1991.

ROSS, S.M. Retention, transformation and mobility of toxic metals in soil-plant systems. In: ROSS, S.M. (Ed.) Toxic metals in soil-plant systems. Chichester: John Wiley, p.63-152, 1994.

SAS INSTITUTE. SAS user's guide: statistics. 5 ed. Carey; SAS Institute, 1985.

SHUMAN, L.M. Effect of phosphorus level on extractable micronutrients and their distribution among soil fractions. Soil Science of America Journal, v.52, p.136-141, 1988.

SILVA, F.A.M. Fracionamento e biodisponibilidade de metais para o feijoeiro (Pahseolus vulgaris L.) em solos tratados com pó de forno de aciaria elétrica. Lavras: UFL, 1999a. 80p. (Mestrado).

SILVA, F.C. Manual de análises químicas de solos, plantas e fertilizantes. Brasília: Embrapa, 1999b. 370p.

TAYLOR, R.W.; IBEABUCHI, I.O.; SISTANI, K.R.; SHUFORD, J.W. Heavy metal concentration in forage and extractabilility from some acid mine spoils. Water, Air and Soil Pollution, v.68, p.363-372, 1993.

TESSIER, A.; CAMPBELL, P.G.C.; BISSON, M. Sequential extraction procedure for the speciation of particulate trace metals. Analytical Chemistry, v.51, p.844-851, 1979.

URE, A.M. Trace elements in soil, soils extracts in solution. Microchymica Acta, v.2, p.49-57, 1991.

ZHANG, T.; SHAN, X.; LI, F. Comparison of two sequential extraction procedures for speciation analysis of metals in soils and plant availability. Communication in Soil Science and Plant Analysis, v.29, p.1023-1034, 1998.

WEAR, J.I.; SOMMER, A.L. Acid-extractable zinc of soils in relation to the occurrence of zinc deficiency symptoms of corns: a method of analysis. Soil Science Society of America Proceedings, v.12, p.143-144, 1947.

Received December 21, 2006

Accepted June 23, 2008 